\title{
The Study of Venture Capital FinanCe and Investment BEHAVIOUR IN SMALL AND MEDIUM-SIZED ENTERPRISES
}

\author{
Thokozani Patmond Mbhele
}

School of Management, IT and Governance, University of KwaZulu-Natal

Accepted: September 2011

\begin{abstract}
Small and medium-sized enterprises (SMEs) are often credited with innovative entrepreneurial practices and conceiving new market opportunities. Government has reinforced these positive economic externalities through policy programmes and designated support structures. Venture capital organisations often galvanise innovative knowledge by entrenching and sustaining nascent businesses through value-creating funding behaviours. In this way, the venture capital industry financially supports entrepreneurial activity for economic growth and governs and nurtures the growth of the SMEs. These show that the venture capital industry embraces value-creating opportunities on the basis of rational partnerships with enterprises that have limited track records and less formal control mechanisms.

The tentative factor analysis findings suggest an integrated framework for the venture capital industry from the significant intercorrelations among the variables. The most important focus of this article, however, is its attempt to examine the behavioural traits of SMEs and venture capitalists regarding systematic finance and investment for inclusivity and due diligence.
\end{abstract}

Key words: investment and financial behaviour, formal and informal venture capital, value options, liquidity patterns, contractual devices, managerial reputation and involvement

JEL: G24

\section{1}

\section{Introduction}

The study attempts to determine the strength of the association between behaviour measures and funding dimensions in the venture capital market. The venture capital industry has had a catalytic role in entrepreneurial development by identifying, financially supporting and nurturing growth-minded businesses with entrepreneurial tenacity. Informal investors, in particular, seek other non-financial returns, among them the creation of jobs in areas of high unemployment, a spur to innovation and the development of technology for social needs. Kuratko and Hodgetts (2004) note that entrepreneurs will continue to be critical contributors to economic growth. This article provides clarity on the blurred distinction between formal and informal venture capital regarding value added abilities. The article is guided by the following research questions:

- What are the underpinning collaborative efforts that influence the optimum funding of small and growing ventures?

- How does the venture capital industry create value added opportunities on the basis of rational partnerships with enterprises that have limited track records and fewer formal control frameworks?

- What integrated framework for the venture capital market will enhance liquidity patterns through financial contracts and options, with intensive managerial involvement in the highly volatile environment?

\section{2}

\section{The meaning of entrepreneurship}

Entrepreneurship is defined as an activity that involves the discovery, evaluation and exploitation of opportunities to introduce new goods and services, ways of organising, markets, processes and raw materials through organising efforts that previously had not existed (Venkataraman, 1997; Shane \& Venkataraman, 2000). Other definitions subscribe 
to the notion of innovation as a key attribute of entrepreneurship. From the perspective of Kirzner (1997), the entrepreneur is an individual who is alert to opportunities for trade. The entrepreneur is capable of identifying suppliers and customers and acting as an intermediary where profit arises out of the intermediary function (Deakins \& Freel, 2006). By contrast, the Schumpeter (1934) perspective involves innovations that result in new combinations that spur creative destruction where the newly created goods, services or firms can hurt existing goods, services or firms (Shane, 2003). Zimmerer and Scarborough (2005) hold that entrepreneurs are new business or combinations that arise in the face of risk and uncertainty for the purpose of achieving profit and growth.

The factors that distinguish entrepreneurs most strongly are innovation, opportunity recognition, process, and growth in a business and employment of strategic management practices in the business (Carland, Boulton \& Carland, 1984; Watson, 2001). 'Innovation involves finding new and better ways of doing things that are commercialised whilst scientific invention entails the creation of a new product or concept almost for its own sake or to serve a purpose other than commerce' (Rwigema \& Venter, 2005:113). Inventors may be motivated by the challenges of solving a problem rather than commercialising their invention. These individuals hold allegiance to idea generation rather than operationalisation and commercialisation. They are concerned with ephemeral satisfaction rather than longterm optimal business commitment and the finance and investment behaviour this implies.

\section{3}

\section{Investment and financial behaviour}

Nascent entrepreneurs depict flexibility in their choice of finance and investment. One of the biggest challenges they face emanates from a trade-off between paying interest and/or giving up some of the ownership with regard to debt and equity respectively. Both debt and equity financing models use covenants to restrict and govern the investee's behaviour and provide additional levers of control in the event that the firm performance is skewed (the firm is constrained and/or restricted from seeking financing elsewhere). Their practices reveal the use of capital rationing through staged financing (venture capital firm-equity capital) and credit limits (banks - debt capital) as a means of controlling the investee's ability to continue and grow their business. Although banks' monitoring and control rights are less intensive, they monitor for covenant violations, deteriorating performance, or worsening collateral quality that might jeopardise their loan (Winton \& Yerramilli, 2008). Landier (2003) notes that entrepreneurs choose safe projects backed by bank debt and low monitoring if the stigma associated with failure is high, and risky projects backed by venture capital finance and high levels of monitoring if the stigma associated with failure is low. For Ueda (2004), the choice between bank and venture capital financing depends on the relative importance of more accurate screening and the level of intellectual property rights protection. Venture capital firms present a distinct form of financial intermediation primarily through the governance and valueadded that the investor provides to the investee (Rwigema \& Venter, 2004).

\section{4}

\section{Formal venture capital}

The term venture capital is sometimes used as a synonym for private equity, meaning private capital invested in businesses outside of the public equity markets. According to King (2008) venture capital firms operate in a rapidly changing environment. Normally, venture capitalists are looking for features such as competent management, competitive edge, growth potential, a viable exit strategy and other intangible factors (Smart, Megginson \& Gitman, 2004). Venture capital funds generally seek out investments that are intermediate term, equity-related investments, that target technology-based private firms and invest in those rare firms that have the potential of going public or being acquired at a premium within a few years (Gompers \& Lerner, 2001). This involves helping firms develop compensation and human resources policies; hiring key executives, such as the marketing president; and intervening to replace poorly- 
performing managers early enough to promote effective change.

Although informal venture capital provides a different perspective in terms of sector coverage and degree of risks absorption, Shepherd and Zacharakis (2002) stress that the trend towards concentration of venture capital under the control of a few firms is increasing.

\section{5}

\section{Informal venture capital and Business Angels}

There is a distinction between formal venture capital as a corporation or partnership that operates as an investment group and angel investors, who are wealthy individuals who are looking to invest in new ventures that show potential (Nieman, 2006). Simmons and Kaplan (2003) describes business angels as individual investors and/or a group of syndicates who use their own wealth to fund a business venture. This business model can be the best option for entrepreneurs to pursue when self-funding and funding from family and friends is not a viable option. Angel investors and angel networks (a handful of investors pooling their funds) are wealthy individuals who provide the money for their investments out of their own pockets (Nieman, 2006). Entrepreneurs are presented with an opportunity to negotiate with angel investors and arrive at personalised investment packages that benefit both parties (Winton \& Yerramilli, 2008). Chemmanur and Chen (2006) suggest that angel investors tend to enjoy a more informal and relational partnership with their entrepreneurs, based on trust and empathy. Researchers refer to empathy as the entrepreneur's feelings for the angel, which further induces him/her to choose the angel over venture capital. The angel-finance sector is characterised by less formal, more empathetic, trusting entrepreneur-angel relationships.

Contrarily, Hellman and Puri (2002) found that venture capital-backed firms are likely to have higher measures of professionalisation than start-up firms that rely on other types of financing. This is consistent with venture capitalists playing a more active role in the firm's management. In the case of very low angel empathy, Fairchild (2009) reports that the entrepreneur focuses on the financiers' value-creating abilities, and therefore prefers to choose a venture capitalist. The angels rely on trust in lieu of formal control, and Wong (2002) notes that the entrepreneur appeals to sociological networks and uses local ties to generate internal funding for the venture. Elitzur and Gavious (2003) add that angels may be relatives of the entrepreneur, or former successful entrepreneurs from the same industry, seeking to help similar new companies. Angels' overriding objectives are often to create employment, promote equity and black empowerment, and develop communities (Kuratko \& Hodgetts, 2004; Wickham, 2001). The entrepreneurs' major challenge lies in finding business angels because the angels market is fragmented and disorganised in number of aspects. The network should not only incorporate venture capital and entrepreneurs but the government must show a certain degree of support and availability. Elitzur and Gavious (2003) emphasise the involvement of relatives of the entrepreneur and former successful entrepreneurs from the same industry that seek to help similar new companies.

\section{6}

\section{Investment and finance decisions}

The interactions between investment and finance decisions are substantially more complex for a small, private or start-up business than they are for a public corporation. Among other things, appropriate application of the finance paradigm implies that the value placed on a new venture will be very different for the entrepreneur than for many outside investors (Smith and Smith, 2000). Because the entrepreneur is usually compelled to invest a significant amount of time and financial capital in a venture, simple adjustments to the net present value (NPV) cannot be used to address the divergence of valuations between the entrepreneur and the market under systemto- time value of money. The NPV may either understate or overstate a project's value, depending on whether the proposed investment creates or destroys future options for the firm.

Kollmann and Kuckertz (2009) describe the venture capital investment process over the 
complete venture capital cycle (Gompers and Lerner, 2000); firstly, the venture capitalists raise funds (fundraising), and invest those funds in an investment process (deal origination, screening, evaluation, structuring), Secondly, they manage their investments once an investment decision has been made (monitoring and value adding) (Jain, 2001; Chen, 2009). Thirdly, they eventually realise any profits from their investments (exit) (Mason \& Stark, 2002). The reality is that most investing involves a process of acquiring, retaining, exercising and abandoning options (Black \& Scholes, 1973).

\subsection{Venture capitalists' value of options}

The right to buy or sell a share at a fixed price can be extremely valuable for investors, provided the price of the underlying stock moves in the right direction. Brealey, Myers and Marcus (2006) describe an option as the opportunity to trade in the future on terms that are fixed today. The values of real options associated with an investment depend on the level of uncertainty surrounding the investment. Real options create economic value by generating future decision rights, or more specifically, by offering management the flexibility to act upon new information. Consequently, the upside economic potential of an investment project is retained, while the downside losses are contained (Trigeorgis, 1996). One factor central to the real options theory is uncertainty, whereby uncertainty in venture capital investments can be attributed to unexpected market developments. Pindyck (1993) reports that such market uncertainty is out of the control of entrepreneurs or venture capitalists, and should thus be viewed as exogenous to organisational activity.

According to $\mathrm{Li}$ (2008) the real options theory on investment suggests that in a world of uncertainty, when investments are at least partially irreversible (Dixit \& Pindyck, 1995), the option to invest can be more economically valuable than immediate investment. This option offers management the flexibility to defer the investment decision until additional information is revealed (McGrath \& Nerkar, 2004). Research by Wang and Zhou (2004) suggests that venture capital firms can stage their financing to mitigate information asymmetry and agency problems. From the structural point of view, Sanz and Lazzaroni (2009) identify four integral formal investment deals. Firstly, the deal has to be fair without constraints on the investment-related cash flows; secondly, the entrepreneur has to feel as much ownership over the company as possible; thirdly, the fund has to have a reasonable chance to exit the investments and realise a positive interest; and fourthly, the deal has to be simple (easy to explain and understand). In fact, a new venture can be viewed most accurately as a portfolio of real options, some controlled by the entrepreneur and others controlled by outside investors. The staging of capital infusions, abandonment of the project, acceleration of the growth rate and a variety of other choices involve real options (Brealey, et al., 2006). The investment that has an embedded real option relies on managers who react to changes in the environment in ways that alter an investment's value. However, the venture capital perspective concentrates on high return earnings, which coincide with liquidity patterns.

\subsection{Liquidity patterns}

A liquidity event can occur in a public offering of equity by the venture or private acquisition of the venture for cash or freely tradable shares of the acquirer. According to Cooper (1993), the objective of the entrepreneur, in deciding whether to pursue the venture and how to structure the financing, is to maximise the value of the financial claims and other benefits that the entrepreneur is able to retain as the business grows. However, Timmons (1994) indicates that it is easy to envision cases where the objective of maximising share value would not be in the entrepreneur's best interest. This is particularly true if the entrepreneur is unable to convince outside investors of the true value of the project and would, therefore, have to give up too large a fraction of ownership, or if the entrepreneur values other considerations besides share value.

Lerner and Schoar (2004) report that venture capital funds impose liquidity restrictions on their investors so as to shield themselves from liquidity shocks. To compensate for the lack of liquidity, Winton and 
Yerramilli (2008) note that fund investors demand a higher return, which in turn causes venture capital funds to require a high return from the firm. In other words, greater skewedness means that the institution can recoup its investment only by taking high payments when the firm is successful, so that it gains more from active monitoring of the firm's strategic decisions. Dushnitsky and Lenox (2005) and Global Insight (2007) maintain that venture capital has an increasingly important impact on corporate innovation, job creation and economic growth, and that venture capitalists should focus on monitoring entrepreneurs closely and invest frequently (Neher, 1999). Venture capital needs to understand the intentions of entrepreneurs and manage the relationship with the entrepreneur to reduce the agency costs of inefficient continuation (Gompers, Kovner, Lerner \& Scharfstein, 2008). The contractual obligation can also reinforce the need for a concerted effort to maximise share value and the prospects of success.

\subsection{Contractual devices}

Timmons and Sapienza (1990) state that contractual devices transfer substantial control over the ultimate success of a venture to outside investors. Myers and Majluf (1994) provide the entrepreneurial perspective by suggesting that it is important to ensure that outside investors do not stop investing or make other changes that are incompatible with the entrepreneur's interests. Winton and Yerramilli (2008) found that the firm's optimal continuation strategy is affected by the subtle details of the firm's situation between two critical parameters: firstly, safe (venture capital firm liquidates poorly performing investments; entrepreneur discontinues skewed outcomes). Secondly, aggressive or risky decisions (venture capital firm intensifies monitoring; entrepreneur retains or expands his/her control benefits and/or institutes an initial public offering (IPO)) that do not always maximise contractible cash flows. Normally, venture capital firms reveal whether a firm in a good state, is in a high substate, in which the risky strategy is the better choice, or in a medium substate, in which the safe strategy is the better choice. Admati and Pfleiderer (1994) and
Gompers (1998) outline distinct phases of staging investments as a contracting device, such as putting off investment decisions until the investor gains experience with the entrepreneur. The use of convertible shares by the investor may discourage the entrepreneur from excessive risk-taking, yet it is appropriate with venture capital firms to entrench and sustain their performance and recognition.

\section{Reputation and managerial involvement}

Reputation depends on a variety of aspects of the firm, and it is the aggregate culmination of many small procedures, conduct and performance levels, which the venture capital firm maintains. The size of a particular venture capital firm is often a function of its past investment success and reputation (Rosentein, Bruno, Bygrave \& Taylor, 1990). According to Norton (1995), venture capitalists face a tradeoff between a high-risk, high-return strategy with a long-term horizon, or a low-risk, lowreturn strategy with a short-term horizon. The venture capitalists' right to influence the structure of the executive team is a typical part of the contract concluded between venture capital and the company (Kaplan \& Stromberg, 2004; Bernhardt \& Krasa, 2004; Tykvova, 2007) and represents one of the key areas of their involvement. Heger and Tykvova (2009) explain that venture capitalists provide value-added services like management advice and support. They indicate that a more intensive involvement of venture capitalists enhances the probability of change in the initial executive teams.

Silvola (2008) reports that venture capital investors have great power over several areas of business, including business development, strategic decisions and management control. Granlund and Taipaleenmaki (2005) note that management control systems help growing firms to move on along with their organisational life cycle. Management control systems create structure; sound decisionmaking and a soothing environment to evolve reputed actors. In the positive view, a good reputation attracts potential investors and helps develop useful working relationships with 
entrepreneurs and other service providers. Formal or informal venture capitalists with a good reputation also benefit from less costly and larger fund raising for future partnerships (Nahata, 2008). Interestingly, Dimov and Milanov (2009) suggest that novel investments are more likely to be syndicated, whereby the venture capital firm's status and reputation provide nuances to this relationship. Since the venture capital community is small and networked, reputation effects echo loudly, and can easily damage a carefully built reputation (Sapienza \& Korsgaard, 1996).

\section{8}

\section{Research methodology}

\subsection{Data acquisition and sampling technique}

The study was conducted using primary data collected through questionnaires. Secondary data has been acquired from companies' records, archives, books and websites with the intention of gaining insight into the industry as a whole. A cross-sectional self-administered survey in the KwaZulu-Natal, Durban region in South Africa was used for data collection. The target sample frame consisted of entrepreneurs in the eThekwini Municipality SMMEs Fair participants. The study has population of approximately 500 participating respondents and the sample size is 160 out of 200 distributed questionnaires, the probability of selection is 32 per cent. The sample size was randomly (simple random sampling) drawn from the target population list. In probability sampling, the searcher uses a random selection of elements to reduce or eliminate sampling bias. The sampling procedure can have substantial confidence that the sample is representative of the population from which it is drawn. All responses were carefully scrutinised for completeness, consistency and errors, and to eliminate questionable data. The responses included nominal data (biographical data and general experience with venture capital firms), as well as ordinal data on a fivepoint Likert-type scale with end points of 'strongly disagree' and 'strongly agree' to measure the items. The processing of the data was done by means of the SPSS program to retrieve univariate, bivariate, and multivariate results.

\subsection{Methods}

The univariate technique was used to summarise and examine the distribution of cases on one variable at a time, while the bivariate technique used the cross-tabulation and chi-square statistic test. Factor analysis as a multivariate technique addressed the problem of analysing the structure of the interrelationships (inter-correlations) among a large number of variables by defining a set of common underlying dimensions, known as factors (Hair et al., 1998). The interpretation of factor analysis is inclined to an underlying view of how strongly each variable is correlated with every other variable in an attempt to identify clusters of variables and/or search for structure among a set of variables.

Rugg (2007) reports that within each cluster, the variables will all correlate fairly strongly with one another on presumption of being variants on a single theme. The application of factor analysis in the study is to understand the complex relationships of scores (multidimensional statistics) on entrepreneur funding dynamics for each underlying dimension and substitute them for the original variables. Cooper and Schindler (2008) clarify that the predictor-criterion relationship is replaced by a matrix of intercorrelations among several variables, none of which is viewed as being dependent on another. The interdependence of factors will assist to understand the way for outsiders (formal and informal venture capital firms) to supply equity profitably to small and growing business entrepreneurs with limited experience and track records in the financial system. The central challenges are converged around the initial stages of deal origination (screening and due diligence), and safe and risky decisions on value creating, liquidity, options and contracts, and managerial control.

\subsection{Cross tabulation and Chi-square}

Cross-tabulation is a technique for comparing two classification variables (Cooper et al., 2008:459) while Chi-square statistic is used to test the statistical significance between the frequency distribution of two or more groups 
(Hair Jr et al., 2003:263). The statistic tests the 'goodness of fit' of the observed distribution with the expected distribution.

Table 1 indicates the number of responses on the screening process (yes or no) on each group of venture capital market (informal and formal). The null hypothesis, $\mathrm{H}_{0}$, is that there is no difference between the venture capital types and the screening process. The alternative hypothesis, $\mathrm{H}_{1}$, is that there is a difference between venture capital types and the screening process. The probability is 0.05 that a true null hypothesis will be rejected. The critical value for one degree of freedom and the 0.05 level of significance is 3.841 with $p$ value $(0.009)$ less than the level of significance

Table 1

Venture capital market - screening process cross-tabulation

\begin{tabular}{|c|c|c|c|c|c|c|}
\hline & & & & \multicolumn{2}{|c|}{ Screening process } & \multirow[b]{2}{*}{ Total } \\
\hline & & & & Yes & No & \\
\hline \multirow{2}{*}{ Venture capital market } & Informal VC & \multicolumn{2}{|c|}{$\begin{array}{l}\text { Count (observed) } \\
\text { Expected count } \\
\% \text { of Total }\end{array}$} & $\begin{array}{l}46 \\
41 \\
35 \%\end{array}$ & $\begin{array}{l}37 \\
42.1 \\
20 \%\end{array}$ & $\begin{array}{l}27 \\
27 \\
55 \%\end{array}$ \\
\hline & Formal VC & \multicolumn{2}{|c|}{$\begin{array}{l}\text { Count (observed) } \\
\text { Expected count } \\
\% \text { of Total }\end{array}$} & $\begin{array}{l}33 \\
38.1 \\
13.3 \%\end{array}$ & $\begin{array}{l}44 \\
39 \\
34.7 \%\end{array}$ & $\begin{array}{l}77 \\
77 \\
45 \%\end{array}$ \\
\hline \multirow[t]{2}{*}{ Total } & \multicolumn{3}{|c|}{$\begin{array}{l}\text { Count } \\
\text { Expected count } \\
\% \text { of Total }\end{array}$} & $\begin{array}{l}79 \\
79 \\
48.3 \%\end{array}$ & $\begin{array}{l}81 \\
81 \\
51.7 \%\end{array}$ & $\begin{array}{l}160 \\
160 \\
100 \%\end{array}$ \\
\hline & Value & df & $\begin{array}{l}\text { Asymp.Sig. } \\
\text { (2-sided) }\end{array}$ & & & \\
\hline $\begin{array}{l}\text { Pearson Chi-square } \\
\text { Likelihood ratio } \\
\mathrm{N} \text { of valid ases } \\
\text { Minimum expected frequency } \\
\text { Cells with expected Frequency }\end{array}$ & $\begin{array}{c}6.877 \\
7.034 \\
160 \\
38.05 \\
<51 \text { of } 2(.0 \%)\end{array}$ & ) & $\begin{array}{l}.009 \\
.008\end{array}$ & & & \\
\hline
\end{tabular}

(0.05). The value of chi-square $\left(\chi^{2}\right)$ test $(6.877)$ is beyond the critical value (3.84), and the decision is to reject $\mathrm{H}_{0}$ at the 0.05 level of significance and accept $\mathrm{H}_{1}$.

It denotes that there is a difference between venture capital types (informal and formal venture capital) and the screening process for SMEs in the venture capital market. The descriptive statistical analysis divulges fairly even spread in that 55 per cent of the respondents prefer informal venture capital while the respondents (52 per cent) perceive that the screening process is not adversary and harsh. Table 2 provides clarity on venture capital market preference and the stages of development for SMEs. In the start-up and early growth stages, SMEs prefer informal venture capital and they perceive the screening process as adversorial and harsh. Goldfarb, Hoberg, Kirsch and Triantis (2007) also note that business angels invest in the early stage of the deal, although they demand fewer controls than venture capitalists. In a similar vein, angels are a primary source of start-up capital for firms in the embryonic stage, through the growth stage and their role in financing small businesses is significant (Zimmerer \& Scarborough, 2005). The seed and expansion stages prefer formal venture capital and they perceive no adversity in the selection and screening process.

\subsection{Reliability assessment}

The reliability of the instrument was operationalised using the internal consistency method that is estimated using Cronbach' Alpha (Cronbach, 1951; Nunnaly, 1978). Cronbach's Alpha values show construct validity that the constructs are measured with sufficient reliability and the Cronbach alpha of the instrument is 0.79 from five point Likert-type scale of sixteen variables ranging from 'strongly disagree' to 'strongly agree'. This figure accords to the minimum of 0.7 suggested by Nunnaly (1978) as a rule of thumb and it also confirms the reliability of the instrument, as factor analysis is used to reduce the total number of items to manageable factors. 


\section{Table 2}

Venture capital market preference and Stage of development

\begin{tabular}{|c|c|c|c|c|c|}
\hline & & & \multicolumn{2}{|c|}{ VCM preference } & \multirow[b]{2}{*}{ Total } \\
\hline & & & Informal & Formal & \\
\hline \multirow{5}{*}{ Stage of development } & Seed & $\begin{array}{l}\text { Count (observed) } \\
\text { Expected count }\end{array}$ & $\begin{array}{l}13 \\
13.9\end{array}$ & $\begin{array}{l}14 \\
13.2\end{array}$ & $\begin{array}{l}27 \\
27\end{array}$ \\
\hline & Start-up & $\begin{array}{l}\text { Count (observed) } \\
\text { Expected count }\end{array}$ & $\begin{array}{l}22 \\
20.5\end{array}$ & $\begin{array}{l}17 \\
18.5\end{array}$ & $\begin{array}{l}39 \\
39\end{array}$ \\
\hline & Early Growth & $\begin{array}{l}\text { Count (observed) } \\
\text { Expected count }\end{array}$ & $\begin{array}{l}19 \\
17.7\end{array}$ & $\begin{array}{l}15 \\
16.3\end{array}$ & $\begin{array}{l}34 \\
34\end{array}$ \\
\hline & Expansion & $\begin{array}{l}\text { Count (observed) } \\
\text { Expected count }\end{array}$ & $\begin{array}{l}17 \\
17.7\end{array}$ & $\begin{array}{l}18 \\
16.3\end{array}$ & $\begin{array}{l}34 \\
34\end{array}$ \\
\hline & Replacement \& buyout & $\begin{array}{l}\text { Count (observed) } \\
\text { Expected count }\end{array}$ & $\begin{array}{l}13 \\
13.3\end{array}$ & $\begin{array}{l}13 \\
12.7\end{array}$ & $\begin{array}{l}26 \\
26\end{array}$ \\
\hline Total & & $\begin{array}{l}\text { Count } \\
\text { Expected count }\end{array}$ & $\begin{array}{l}83 \\
83\end{array}$ & $\begin{array}{l}77 \\
77\end{array}$ & $\begin{array}{l}160 \\
160\end{array}$ \\
\hline
\end{tabular}

\subsection{Factors describing venture capital funding market}

Factor analysis was performed on percentage of total variance of all six items explained by three factors of about 79 per cent. Tabachnick and Fidell (2001) concede that a smaller sample size of 150 cases should be sufficient despite the comforting 300 cases for factor analysis, and solutions should have high loading marker variables. The reliability of factor structures and the sample size requirements are congruent with factor loading above 0.80. However, Dancey and Reidy (2002) note that when performing factor analysis, at least 100 participants should be variables. Both of these criteria were met by the present study, with six and ten item measure and 160 respondents. The statistical measures have assisted to assess the factorability of the data with Bartlett's Test of Sphericity (Bartlett, 1954), and the KaiserMeyer-Olkin (KMO) measure of sampling adequacy (Kaiser, 1970, 1974). The Bartlett Test of Sphericity is significant $(0.000<0.05)$ for the factor analysis to be considered appropriate. The measure indicates that the Kaizer-Meyer-Olkin (KMO) score of 0.82 (indicates sampling adequacy) obtained in this factor analysis is suitable with Bartlett's Test of Sphericity (107.54) at degree of freedom (15). The factor model indicates three distinct factor loadings without any misclassifications (a total of six items are reduced to three underlying factor loadings).

The principal component methods of factor extraction and Varimax methods of rotation generated three factors that account for 79.44 per cent of the variance. Principal components analysis is used to extract factors with eigenvalues greater than one (Podsakoff \& Organ, 1986), while varimax rotation is used to facilitate interpretation of the factor matrix. Factor 1 accounts for 43.60 per cent of the variance, factor 2 for 18.13 per cent and factor 3 for 17.71 per cent. Table 3 indicates that these three factors accounted for 79.44 per cent of the variance in the original six variables. The percentage exceeds the minimum amount of variance of 60 per cent and the number of original variables has been reduced from six to three. All three factors have eigenvalues above the customary cut-off point of one. The factors are set out in Table 4.

Column one of Table 4 shows the names of the six variables. It is easier to interpret the factor solution, if factor loadings under $<0.50$ in the factor matrix are not reflected. There are only three factors retained in this analysis with eigenvalues $>1$.

\subsubsection{Analysing factors}

The logic of naming the factors is easily supportable and theoretically sound. One creates an artificial dimension that would highly correlate empirically with each of the items measuring prejudice (Babbie \& Mouton, 2001).

Factor 1: The critical factor comprises items from liquidity patterns, real options, communication and entrepreneur's knowledge. This factor describes market relations and behaviour in new venture investments that do 
Table 3

Total variance explained: venture capital funding market

\begin{tabular}{|c|c|c|c|}
\hline \multirow{2}{*}{ Component } & \multicolumn{3}{|c|}{ Rotation sums of squared loadings } \\
\cline { 2 - 4 } & Total eigenvalues & \% of variance & Cumulative \% \\
\hline 1 & 2.616 & 43.600 & 43.600 \\
\hline 2 & 1.088 & 18.130 & 61.730 \\
\hline 3 & 1.063 & 17.711 & 79.441 \\
\hline
\end{tabular}

Table 4

Rotated component matrix

\begin{tabular}{|l|c|c|c|}
\hline \multicolumn{1}{|c|}{ 1.1.1.1.1 Component } & $\mathbf{1}$ & $\mathbf{2}$ & $\mathbf{3}$ \\
\hline Liquidity & 0.855 & & \\
\hline Real options & 0.832 & & \\
\hline Communication & 0.785 & & \\
\hline Entrepreneur's knowledge & 0.725 & & \\
\hline Lack of financing & & 0.942 & \\
\hline Good ideas & & & 0.961 \\
\hline
\end{tabular}

not generate any significant free cash flow for several years. Although the reasons for real options associated with an investment depend on the level and uncertainty surrounding the investment, it is difficult for the entrepreneurs to communicate their true beliefs about the potential success of a new venture. This suggests that the entrepreneurs know more about their abilities, managerial skills and commitment than the outsiders.

Factor 2: This factor describes the lack of funding as the most likely factor that will destroy an excellent idea.

Factor 3: This factor describes the possibility of identifying and investing in good ideas, even though it is difficult to find people who can implement the ideas. Figure 1 indicates the major dimensions that influence the venture capital market.

\subsection{Factors describing the perceptions of informal venture capital (Business Angels, friends and relatives)}

The Kaiser-Meyer-Oklin is 0.596 (rounding off, 0.60), equating the recommended value (KMO index ranges from 0 to1) (Kaiser, 1970, 1974) and the Bartlett's test of sphericity (Bartlett, 1954) reaches statistical significance $(0.000<0.05)$. The fact that the significance level is very small $(p=0.000)$ indicates that there are significant relationships among the variables. Scale reliability provides a measure of the internal consistency and homogeneity of the items comprising a scale, and Churchill (1979) suggests that all constructs displaying composite reliabilities in excess of 0.60 are recommended value for studies. Cronbach's alpha of the instrument is adequate at 0.62 .

Table 5 shows that four factors accounted for 75.50 per cent of the variance in the original ten variables. The percentage exceeding minimum amount of variance and variables has been reduced from the original ten variables to four. Principal components analysis reveals the presence of four components with eigenvalues exceeding one, explaining 22.7 per cent, 21.1 per cent, 20.4 per cent and 11.1 per cent of the variance respectively.

\subsubsection{Analysis of the factors}

Factor 1: The critical component comprises items from non-financial returns, willingness and equity gap. This factor relates to nonfinancial returns and willingness for job creation from fairly patient informal investors. These investors seek to close both the equity gap and the people/experience gap which constrain the development of SMEs.

Factor 2: The component two is interpreted as stages of investment from items of industrial sectors and stages, choice of investment location, and first approach and receipt of funds. 


\section{Table 5}

Total variance explained: perceptions towards informal venture capital

\begin{tabular}{|c|c|c|c|}
\hline \multirow{2}{*}{ Component } & \multicolumn{3}{|c|}{ Rotation sums of squared loadings } \\
\cline { 2 - 4 } & Total eigenvalues & \% of variance & Cumulative \% \\
\hline 1 & 2.279 & 22.785 & 22.785 \\
\hline 2 & 2.117 & 21.167 & 43.952 \\
\hline 3 & 2.042 & 20.416 & 64.368 \\
\hline 4 & 1.113 & 11.134 & 75.502 \\
\hline
\end{tabular}

Factor 3: The critical component comprises items from syndicate approach, limited ability and business networks, and it is interpreted as business networks.

Factor 4: This component is interpreted as target-oriented performance, where the investment structure for informal venture capitalists allows the entrepreneurs to regain control.

\subsection{Validity}

The study looks at validity as an extent to which a scale or set of measures accurately represents the concept of the venture capital industry. Bryman and Bell (2007) report that there are a number of ways of investigating the merit of measures (validity and reliability), that are devised to represent social scientific concepts. The researcher intends to identify theoretically supported relationships from prior research or accepted principles and then assess whether the scale has corresponding relationships. Nomological validity is utilised for this study. It refers to the degree that the summated scale makes accurate predictions of other concepts in a theoretically based model (Hair $\mathrm{Jr}$ et al., 1998). Convergent validity is demonstrated when a set of alternative measures accurately represent the construct of interest (Churchill, 1979). For this study, convergent validity was assessed by reviewing the level of significance for the factor loadings. If all the individual item's factor loadings are significant, then the indicators are effectively converging to measure the same construct (Anderson \& Gerbing, 1988). The constructs are significant at level $p=0.000$, providing satisfactory evidence of convergent validity and unidimensionality of each construct.

\subsection{Dimensionality}

The factor analysis in this study has produced multiple dimensions where each dimension is reflected by a separate factor and ultimately naming those factors. It means that items are strongly associated with each other and represent a single concept. The test of unidimensionality is that each summated scale consists of items loading highly on a single factor because it facilitates the naming of factors. Table 6 shows highly loaded items on each scale like non-financial returns and job creation, industrial sectors and stages, syndication approach and investment structure and each item is summated on the basis of high loadings.

\subsection{Homoscedasticity and heteroscedasticity}

Heterogeneity of the respondents has shown a share variance among variables as the underlying component factor models on Table 4 and Table 6. The first factors have represented those variables that are more homogeneous across the entire sample in the factor analysis. Furthermore, the higher loadings and rotation of the factors (tables 3 and 5) have improved interpretation and naming of factors.

\section{9}

\section{Discussion and conclusion}

The factor loading has presented the positive relationships among the variables, which have been named. There is an increased reliability value with the same degree of intercorrelation and reliability of the instruments used. Sampling adequacy measurement tests were examined via Kaizer-Meyer-Olkin statistics to validate the use of factor analysis. The KMO Score is closer to one on both Barlett's test with the level of significance equating to 0.000 , which indicates significant relationships among the variables. The reduction of 
Table 6

Rotated component matrix

\begin{tabular}{|l|c|c|c|c|}
\hline \multicolumn{1}{|c|}{ Component } & $\mathbf{1}$ & $\mathbf{2}$ & $\mathbf{3}$ & $\mathbf{4}$ \\
\hline Non-financial returns and job creation & 0.870 & & & \\
\hline Patience and willingness & 0.801 & & & \\
\hline Equity gap and people gap & 0.796 & & & \\
\hline Industrial sectors and stages & & 0.878 & & \\
\hline Choice of location & & 0.865 & & \\
\hline First approach and receipt of funds & & 0.661 & & \\
\hline Syndication approach & & & 0.871 & \\
\hline Limited ability & & & 0.771 & \\
\hline Business networks & & & 0.770 & \\
\hline Investment structure & & & & 0.951 \\
\hline
\end{tabular}

variables has condensed the information contained in a number of variables into a smaller set of new and composite multiple dimensions with a minimum loss of information and meaning. A principal component factor analysis was conducted on all original measurement items, and this analysis yielded three significant factors with eigenvalues greater than one, explaining 79.4 per cent of variance (43.6 per cent, 18.1 per cent and 17.1 per cent respectively for each factor) in the venture capital funding market. The perceptions of informal venture capital produced four significant factors with eigenvalues greater than one explaining 75.5 per cent (22.7 per cent, 21.1 per cent, 20.4 per cent and 11.1 per cent respectively for each factor). These results denote that the data were not explained by a single common method factor (Podsokoff \& Organ, 1986), and it can be suggested that there is no evidence of common method bias with the data collected.

\subsection{Formal venture capital}

The venture capital market epitomises behaviour that is linked to high returns on investments, although the angel-finance sector is characterised by more emphatic and trusting entrepreneur-angel relationships with less control. Additionally, the investee's behaviour is restricted and governed through covenants as levers of control. The behaviour is influenced by rising stock exchange markets and by the lucrative initial public offerings (IPO) markets. Notably, 53 per cent of the respondents acknowledged that it is critically more important to put together a strong enough management team rather than an individualistic approach to see the project through to success and 47 per cent indicated that they had a management team, talent and leadership qualities to sustain the project.

Furthermore, the majority (62 per cent) preferred a certain extent of managerial involvement by outside investors to underpin the venture growth prospects. The rationale for intense involvement emanates from the considerable percentage (58 per cent) that indicated a lack of any track record when starting the venture. Venture capital behaviour should be dependent upon the tremendous information sharing between venture capitalists, entrepreneurs, consultants and a wide range of related actors who operate within the network. Although funds are invested in expansions and leveraged buyouts as surer bets, this behaviour will limit the funds for seed financing and start-ups. Long-term commitment to seed financing and start-ups is commercially successful and promotes innovation and invention in the economy. There is also a propensity to realise the growing demands for financial liquidity for venture investments.

It is puzzling to discover that 58 per cent of the respondents did have initial capital when starting a venture. However, the study reveals that the retail sector ( 40 per cent) offers easy entry and fewer resources and money were needed. The manufacturing sector (27 per cent) shows less interest in entrepreneurship and it presents problems with regard to innovation and inventions. The trend in the SMEs should be on manufacturing with help from the government, particularly the Depart- 
ment of Trade and Industry and the Industrial Development Corporation. Entrepreneurs are exposed to the retail sector and they understand its operations and technical aspects, while the manufacturing sector demands more thorough research and development of the concept. This problem is linked to the implementation process where entrepreneurs identify new venture opportunities and ultimately fail to execute or sustain them. As a result, the investor will be confronted with a difficult-to-recover investment on an unsuccessful project.

\subsection{Informal venture capital}

The study indicates that 62 per cent of the respondents preferred informal venture capital as the most important source of external equity capital from family and relatives. Formal venture capitalists select businesses with a great deal of growth potential because very few ventures meet performance standards. The study indicates that the ventures ( 60 per cent) think that the screening process is adversarial and harsh. Moreover, formal venture capitalists impose a large number of restrictions on the behaviour of entrepreneurs.

The derived factors (Figure 1, downstream) provide suggestions for the solutions of some problems with regard to formal venture capitalists. The factors represent the structural framework for the successful nurturing of a new venture while persistently working towards repetitive benefits and earning returns on investment. The broader perspective from informal venture capital covers the fundamental challenges facing South Africa. These include employment creation, community upliftment, grooming nascent entrepreneurs, promoting various business opportunities, experiential investments, consolidating funds from former colleagues, informal networks (which coincide with entrepreneurial practice) and relaxed procedural screening.

Concentration on these factors will create amicable relationships between venture capitalists, and entrepreneurs in the venture capital market. The transformation process and standard procedures need improvement as new ventures are generally financed by equity rather than by debt. New ventures obviously lack sufficient cash flow to pay interest, because debt financing at a fixed rate of interest encourages entrepreneurs to take risky actions with investors' funds. The due diligence process should at least indicate the estimated break-even point by focusing on the value of the venture opportunity and the entrepreneur's ability to capture that value.

Financial projections are realised only when a good business proposition becomes a reality, not when it is forecast. The actual nature and degree of competition in the market are less important than the team's apparent ability to sustain and protect market share. They also need to make sure that they can convincingly demonstrate leadership ability and the appropriate competencies to potential investors.

\subsection{Conjoint framework of venture capital market}

Figure 1 (both streams) demonstrates the conjoint framework for the venture capital market to transform the industry within the context of entrepreneurial practice and elevate the degree of the approach. The integration of the formal and informal factorial approach will revitalise growth and unify the industry. As a result, entrepreneurs will prefer using a synchronised venture capital system rather than applying for loans or other related financial supports without tangible and intangible values. The negative effects of investment and finance within the industry can be resolved and ultimately become extinct.

The circular format emanates from a conjoint framework (Figure 2) and has been developed and made applicable in a circle formation for constant review and improvement. It also allows a retrospective approach on previous steps before committing on a final, long-term investment and finance decision.

\section{Steps in conjoint venture capital market:}

1) Analyse the finance and investment behaviour in the venture capital market.

2) Identify financial difficulties and challenges in the SMEs.

3) Detect the potential returns on investment and magnitude for intentions/options.

4) Decide on finance and investment decisions among the portfolios.

5) Institute the support structure from privatepublic partnership format. 


\section{Figure 1}

Dimensions influencing the venture capital market (conjoint framework for venture capital market)

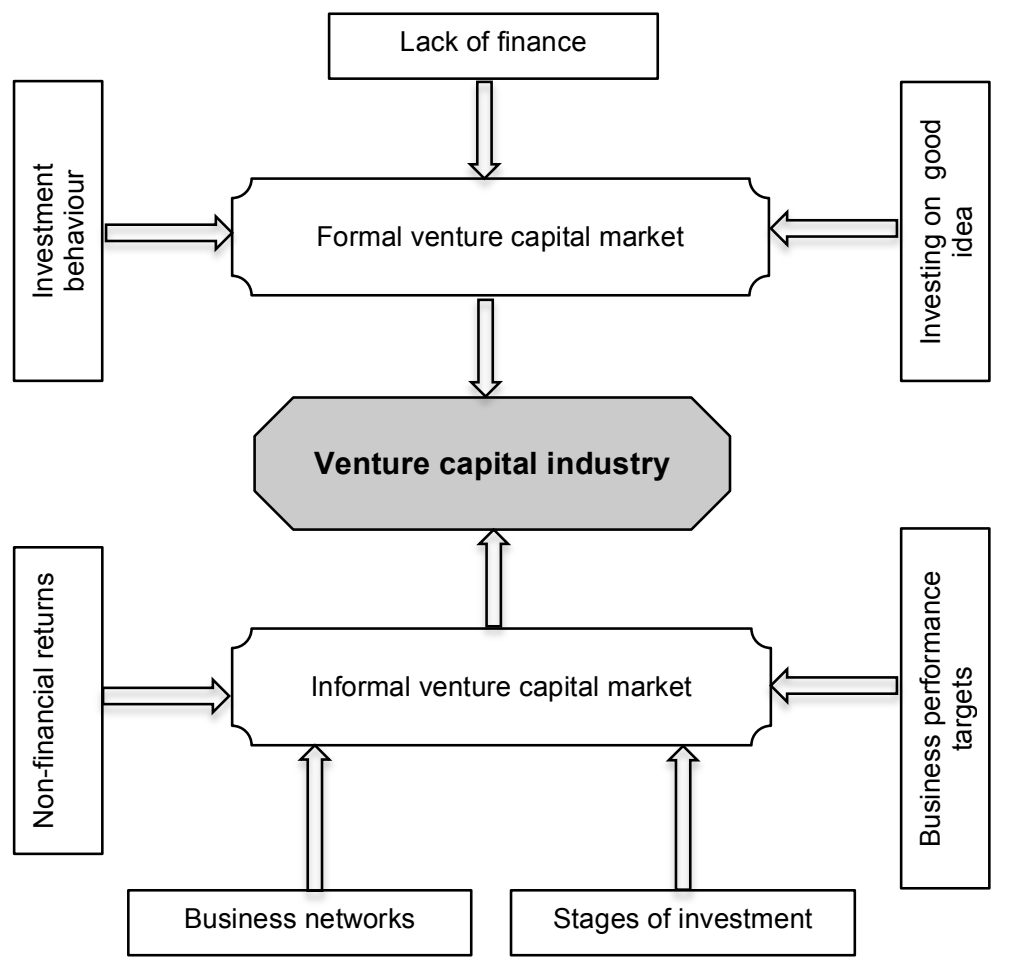

6) Initiate the implementation process with regular control measures in place.

7) Assess the business performance on an interval period for sustainable growth.

Step 1: A thorough understanding of enterprise development on finance and investment should be analysed and categorised in stages of development. The risk profiles will determine the required financial injection, that is, earlier stages carry high risk and the funding of later stages indicates less risk.

Steps 2 and 3: The entrepreneurial finance paradigm ranges on risk profile in relation to expected returns by venture capital. The returns should coincide with level of enterprise development, meaning that the value-creation system emerges on the enterprise and return on investment. The venture capitalist's intentions and the entrepreneur's ambitions and dreams will be attained.

Step 4: The venture capitalist should categorise enterprises in phases, that is, earlier phase and later phase (expansion) into business

portfolio investments. The risk profiles will be the impetus towards sifting for good investment during the screening process.

Step 5: The support structures will range among such factors as: 1) Private sector (the private sector has a capacity to provide technical skills and the capability to absorb technical risks through skills programmes that can be subsidised by government). 2) Government (the propensity for enterprise can be invigorated by simplifying the regulatory environment and be further supported by Broad-based Black Economic Empowerment (BBBEE) codes). 3) Banks (the banking institutions need a complete overhaul with regard to their structural framework. The banks can start by transforming their rigid systems that require an entrepreneur to sign up entire collateral).

Steps 6 and 7: This will be determined by acceptable the guiding principles of each company on instituting a practical implementtation process and further designing the necessary parameters for sustainability. 


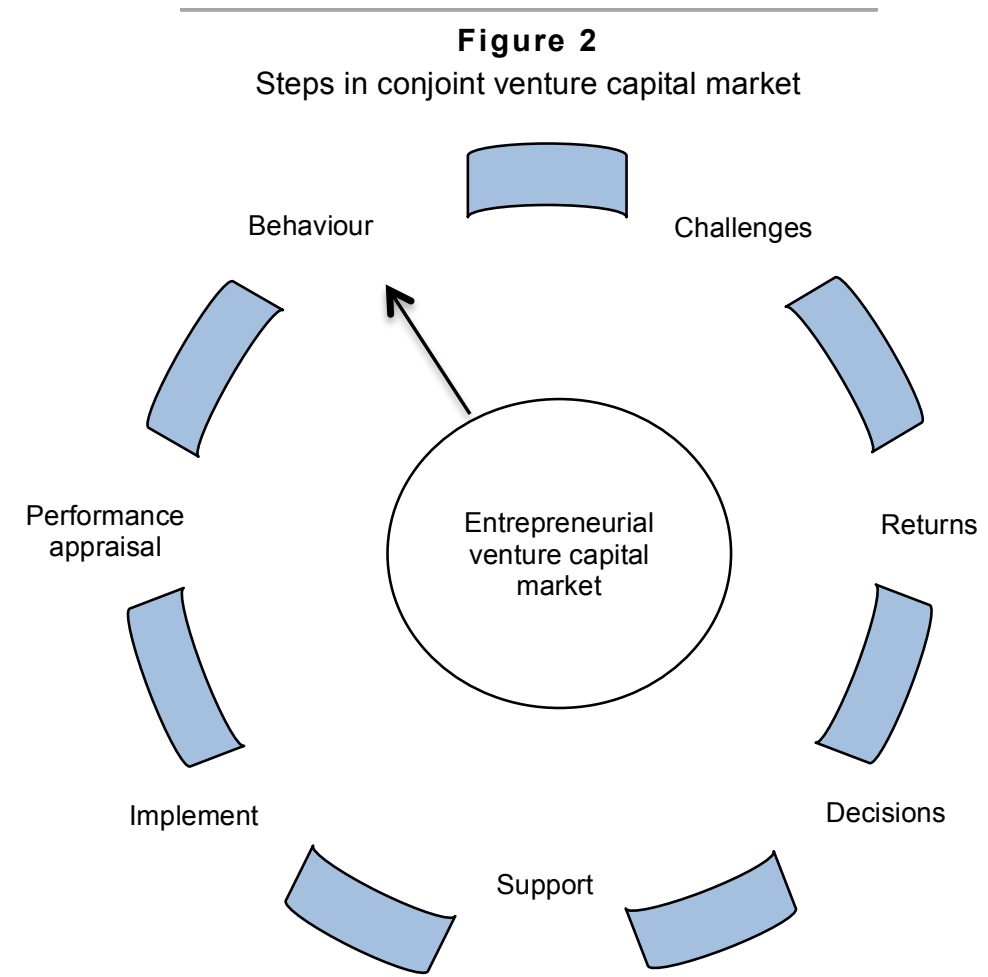

10

\section{Recommendation}

It is recommended that an entrepreneur should discretely work his/her network of acquaintances to see if anyone can make an appropriate introduction. The effort of finding business angels must be facilitated by government support structures such as the Department of Trade and Industry (DTI), the Industrial Development Corporation (IDC) and the Small Enterprise Development Agency (Seda). It is logically appropriate to entrench a systematic referral database of business angels. The identification of angels will do away with the problems of seed funding and skewed performance and ultimately mitigate the rate of failure within SMEs. The pilot project should start with former corporate executive managers from parastatals because the government institutions have records of them. The success of the program can be diffused through publicprivate partnerships. The structured system of business angels can deal with the derived factors (investment intentions, investment decisions, support structures and business performance) because they possess vast experience in those areas. In terms of seemingly adverse selection criteria, professional individuals can conceptualise major requirements to an appropriate level. The majority of parameters in the existing venture capital industry reflect a diverse context in developed economies. The hands-on approach will promote transparent investment opportunities in the abilities and capabilities of entrepreneurs' ideas. The adverse and prejudiced selection process by venture capital firms will be resolved. The venture capital industry is bringing a different perspective to dealing with entrepreneurs' aspirations and dreams. Therefore, the process must shape mere ideas into viable business concepts.

\section{1}

\section{Limitation}

The factor analysis is a single method used in the study, and the conclusions and interpretation cannot be drawn solely on condensing the items into factors. To provide more than one outcome within the factor, regression analysis will be an appropriate method to use after developing the factors, 
and the method will assess the relationship between these factor loadings. The study has a locus coverage of the Durban region, and the sampling techniques do not claim to statistically represent the entire population. However, the objectives have been attained through development of optimal dimensions and the conjoint venture capital market framework on both formal and informal venture capital firms. This is an anomaly but further research can expand and conceptualise these dimensions.

\section{2}

\section{Future research}

A comparative study into formal and informal venture capital firms would assist entre- preneurs in deciding on the viability of adopting one over the other. An electronic database to track business angels and former professional corporate executives will efficiently collate a pool of professionally savvy individuals. SMEs development can be grown through collaboration and experiential learning abilities. Similarly, pooling funds from business angels can provide venture capital for new and unproven businesses. The electronic system can enhance the listing of a multitude of angel investors to provide expertise and funding.

\section{References}

ADMATI, A.R. \& PFLEIDERR, P. 1994. Robust financial contracting and the role of the venture capitalist. Journal of Finance, 49:371-402.

ALDRICH, H. 1999. Organisations evolving. London:Sage.

ANDERSON, J. \& GERBING, D.W. 1988. Structural equation modeling in practice: a review and recommended two-step approach, Psychological Bulletin, 103(2):411-423.

BABBIE, E. \& MOUTON, J. 2001. The practice of social research. South Africa: Oxford.

BARTLETT, M.S. 1954. A note on the multiplying factors for various chi square approximations. Journal of the Royal Statistical Society, 16(Series B):296-298.

BERNHARDT, D. \& KRASA, S. 2004. Informed finance? Unpublished working paper, University of Illinois, Champaign, IL.

BLACK, F \& SCHOLES, M. 1973. The pricing of options and corporate liabilities. Journal of Political Economy, 81:323-329.

BRYMAN, A. \& BELL, E. 2007. Business research methods $\left(2^{\text {nd }}\right.$ ed. $)$ New York: Oxford.

CARLAND, J.W., HOY, F., BOULTON, W.R. \& CARLAND, J.A.C. 1984. Differentiating entrepreneurs for small business owners: a conceptualization. Academy of Management Review, 9(2):354-9.

CHEMMANUR, T. \& CHEN, Z. 2006. Venture capitalists versus angels: the dynamics of private firm financing contracts. Carroll School of Management, Boston College. Working Paper.

CHEN, C. 2009. Technology commercialization, incubator and venture capital, and new venture performance. Journal of Business Research, 62:93-103.

CHURCHILL, G.A. Jr. 1979. A paradigm for developing better measures of marketing constructs, Journal of Marketing Research, 16(1):64-73.

COOPER, A. 1993. Challenges in predicting new firm performance. Journal of Business Venturing, 8: 241-253.

COOPER, D.R. \& SCHINDLER, P.S. 2008. Business Research Methods $\left(10^{\text {th }}\right.$ ed.) Boston: McGraw-Hill. CRONBACH, I.J. 1951. Coefficient alpha and the internal structure of tests, Psychometrika, 16:297-334. DANCEY, C.P. \& REIDY, J. 2002. Statistics without maths for psychology ( $2^{\text {nd }}$ ed.) Hemel Hempstead: Prentice-Hall.

DEAKINS, D \& FREEL, M. 2006. Entrepreneurship and small firms. $\left(4^{\text {th }}\right.$ ed.) London: McGraw-Hill. DIMOV, D. \& MILANOV, H. 2009. The interplay of need and opportunity in venture capital investment syndication. Journal of Business Venturing, pp. 1-18. 
DIXIT, A.K. \& PINDYCK, R.S. 1994. Investment under uncertainty. Princeton University Press, Princeton. DIXIT, A.K. \& PINDYCK, R.S. 1995. The options approach to capital investment. Harvard Business Press, May-June:105-115.

DUSHNITSKY, G \& LENOX, M.J. 2005. When does corporate venture capital investment create firm value? Journal of Business Venturing, 21(6):753-772.

ELITZUR, R \& GAVIOUS, A. 2003. Contracting, signaling, and moral hazard: a model of entrepreneurs, 'angels' and venture capitalists. Journal of Business Venturing, 18:709-725

FAIRCHILD, R. 2009. An entrepreneur's choice of venture capitalist or angel-financing: A behavioural game-theoretic approach. Journal of Business Venturing, pp. 1-16

GLOBAL INSIGHT 2007. Venture impact: the economic importance of venture capital backed companies to the U.S. Economy. ( $3^{\text {rd }}$ ed.) National Venture Capital Association.

GOLDFARB, B., HOBERG, G., KIRSCH, D. \& TRIANTIS, A. 2007. Are angels preferred venture investors? University of Maryland. Working Paper.

GOMPERS, P.A. 1998. Venture capital growing pains: Should the Market Diet? Special issue on the Economics of Small Business Finance. Journal of Banking and Finance, 22(6-8):1089-1 104.

GOMPERS, P. \& LERNER, J. 2001. The venture capital revolution. Journal of Economic Perspectives, 15(2):145-168.

GOMPERS, P.A., KOVNER, A., LERNER, J. \& SCHARFSTEIN, D. 2008. Venture capital investment cycles: The impact of Public Markets. Journal of Financial Economics, 87(1):1-23.

GRANLUND, M. \& TAIPALEENMAKI, J. 2005. Management control and controllership in new economy firms-A life-cycle perspective. Management Accounting Research, 16(1):21-57.

HAIR, J.G. Jr. 1998. Multivariate Data Analysis. USA: McGraw-Hill.

HAIR, J.F. Jr, ANDERSON, R.E., TATHAM, R.L. \& BLACK, W.C. 1998. Multivariate data analysis. $\left(5^{\text {th }}\right.$ ed.) New Jersey: Prentice-Hall International, Inc.

HAIR, J.F. Jr, BABIN, B., MONEY, A.H. \& SAMOUEL, P. 2003. Essentials of Business Research Methods. New Jersey: John Wiley \& Sons, Inc.

HEGER, D. \& TYKVOVA, T. 2009. Do venture capitalists give founders their walking papers? Journal of Corporate Finance, 15:613-625.

HELLMAN, T. \& PURI, M. 2002. Venture capital and the professionalization of start-up firms: empirical evidence, Journal of Finance, 57(1):169-197.

JAIN, B. 2001. Predictors of performance of venture capitalists-backed organizations. Journal of Business Research, 52:223-233.

KAISER, H. 1970. A second generation little jiffy. Psychometrika, 35:401-415

KAISER, H. 1974. An index of factorial simplicity. Psychometrika, 39:31-36

KAPLAN, S.N. \& STROMBERG, P. 2004. Characteristics, contracts and actions: evidence from venture capitalist analyses. Journal of Finance, 59(5).

KOLLMANN, T. \& KUCKERTZ, A. 2009. Evaluation uncertainty of venture capitalists investment criteria. Journal of Business Research, 10:1016

KING, B.L. 2008. Strategising at leading venture capital firms: of planning, opportunism and deliberate emergence. Long Range Planning, 41:345-366.

KIRZNER, I.M. 1997. How markets work: disequilibrium, entrepreneurship \& discovery. Institute of Economic Affairs, Hobart paper No. 133.

KURATKO, D.F. \& HODGETTS, R.M. 2004). Entrepreneurship. (6 ${ }^{\text {th }}$ ed.) Australia: Thomson.

LANDIER, A. 2003. Start-up financing: from banks to venture capital. Unpublished working paper, University of Chicago, Chicago, IL.

LERNER, J. \& SCHOAR, A. 2004. The liquidity puzzle: theory and evidence from private equity. Journal of Financial Economics, 72(1):3-40.

LI, Y. 2008. Duration analysis of venture capital staging: A real options perspective. Journal of Business Venturing, 23:497-512.

MARX, L.M. 1999. Contract renegotiation and renegotiation of venture capital projects. University of Rochester Working Paper.

MASON, C. \& STARK, M. 2002. What do investors look for in a business plan? Paper presented at the $25^{\text {th }}$ ISBA National Small Firms Policy and Research Conference, Brighton, UK. 
McGRAtH, R.G. \& NERKAR, A. 2004. Real options reasoning and a new look at the R\&D investment strategies of pharmaceutical firms. Strategic Management Journal, 25(1):1-21.

MYERS, S.C. \& MAJLUF, N.S. 1994. Corporate financing and investment decisions when firms have information investors do not have. Journal of Financial Economics, 13:261-297.

NAHATA, R. 2008. Venture capital reputation and investment performance. Journal of Financial Economics, 90:127-151

NEHER, D.V. 1999. Staged financing: an agency perspective. Review of Economic Studies, 66(2):147-176.

NIEMAN, G. 2006. Small business management. Hatfield, Pretoria: Van Schaik.

NORTON, E. 1995. Venture capital as an alternative means to allocate capital: An agency-theoretic view. Entrepreneurship: Theory and Practice, 20.

NUNNALY, J.C. 1978. Psychometric theory, New York: McGraw-Hill.

PINDYCK, R.S. 1993. Investments of uncertain cost. NBER Working Paper 4175, National Bureau of Economic Research, Inc.

PODSAKOFF, P.M. \& ORGAN, D.W. 1986. Self-reports in organisational research: problems and prospects. Journal of Management, 12(4):531-544.

ROSE, M 2002. South African micro lending in the face of libaralisation, technological innovation and Aids in Proceedings of the $3^{\text {rd }}$ international conference. International Academy of African business and development. Port Elizabeth, South Africa, 3-6 April.

ROSS, S., WESTERFIELD, R.W., JORDAN, B.D. \& FIRER, C. 2003. Fundamentals of corporate finance. $\left(2^{\text {nd }}\right.$ South African ed.) Sydney: Irwin/McGraw-Hill.

ROSENTEIN, J., BRUNO, A.V., BYGRAVE, W.D. \& TAYLOR, N.T. 1990. How much do CEOs value the advice of venture capitalists on their boards? Frontiers of Entrepreneurship Research (Wellesley, MA: Babson College).

RUGG, G. 2007. Using statistics: A gentle introduction. London: McGraw-Hill.

RWIGEMA, H. \& VENTER, R. 2004. Advanced entrepreneurship. Cape Town: Oxford.

RWIGEMA, H. \& VENTER, R. 2005. Advanced entrepreneurship. Cape Town: Oxford.

SAHLMAN, W.A. 1990. The structure and governance of venture capital organizations. Journal of Financial Economics: 473-521.

SANZ, L.J. \& LAZZARONI, M. 2009. Ago/ra partnerships Micaragua: A micro venture capital fund. Journal of Business Research, 62:902-912.

SAPIENZA,H. \& KORSGAARD, M. 1996. Procedural justice in entrepreneur-investor relations. Academy of Management Journal, 39:544-574.

SCHMIDT, K. 2003. Convertible securities and venture capital finance. Journal of Finance, 58(3): $1139-1165$.

SCHUMPETER, J.A. 1934. The theory of economic development. Translated by R. Opic. Cambrige, MA: Harvard University Press.

SEKARAN, U. 2003. Research methods for business: A skill building approach. US: John Wiley \& Sons. SHANE, S. 2003. A general theory of entrepreneurship: The individual-opportunity Nexus. Northampton, UK: MPG Books ltd.

SHANE, S. \& VENKATARAMAN, S. 2000. Entrepreneurship as a field of research: The promise of entrepreneurship as a field of research. Academy of management review, 26 (1):13-17.

SHEPHERD, D.A. \& ZACKARAKIS, A.L. 2002. Venture capitalists' expertise: A call for research into decision into decision aids and cognitive feedback, 17(1):1-20.

SILVOLA, H. 2008. Do organizational life-cycle and venture capital investors affect the management control systems used by the firm? Advances in Accounting, incorporating Advances in International Accounting, 24: 128-138.

SIMMONS, E.C. \& KAPLAN, J.M. 2003. Patterns of entrepreneurship: Early-stage financing. US: John Wiley and Sons.

SMART, S.B., MEGGINSON, W.L. \& GITMAN, L.J. 2004. Corporate finance. US: Thompson SouthWestern.

SMITH, R.L. \& SMITH, J.K. 2000. Entrepreneurial finance. New York: John Wiley and Sons, Inc. 
TABACHNICK, B.G. \& FIDELL, L.S. 2001. Using multivariate statistics. $\left(4^{\text {th }}\right.$ ed.) New York: HarperCollins.

TIMMONS, J.A. 1994. New Venture Creation: Entrepreneurship for the $21^{\text {st }}$ Century. New York: McGrawHill.

TIMMONS, J. \& SAPIENZA, H.J. 1990. Venture capital: more than money? Needham, MA: Venture Economics, Inc., 36-41.

TIMMONS, J.A. \& SPINELLI, S. 2006. New venture creation: entrepreneurship for the $21^{\text {st }}$ century. $\left(7^{\text {th }}\right.$ ed.) Boston: McGraw-Hill.

TRIGEORGIS, L. 1996. Real options: managerial flexibility and strategy in resource allocation. London: MIT Press.

TYKVOVA, T. 2007. What do economists tell us about venture capital contracts? Journal of Economic Surveys, 21(1):65-89.

UEDA, M. 2004. Banks versus venture capital: project evaluation, screening, and expropriation. Journal of Finance, 59(2):601-621.

VENKATARAMAN, S. 1997. The distinctive domain of entrepreneurship research. US: JAI Press, Greenwich.

VENTER, R. 2004. Financing new ventures. Cape Town: Oxford Press.

WANG, S.S. \& ZHOU, H.L. 2004. Staged financing in venture capital: Moral hazard and risks. Journal of Corporate Finance, 10(1):131-155.

WATSON, C.H. 2001) Small business versus entrepreneurship revisited. In: Brockhans, R.H. (ed.) Entrepreneurship education: a global view. Burlington:Ashgate.

WELMAN, J.C., KRUGER, S.J. \& MITCHELL, B.C. 2005. Research Methodology. (3 ${ }^{\text {rd }}$ ed.) Cape Town: Oxford University Press Southern Africa.

WINTON, A. \& YERRAMILLI, V. 2008. Entrepreneurial finance: Banks versus venture capital. Journal of Financial Economics, 88:51-79.

WICKHAM, P.A. 2001. Strategic Entrepreneurship. (2 $2^{\text {nd }}$ ed.) London: Pearson Education.

WONG, A. 2002) Angel Finance: The Other Venture Capital. University of Chicago. Working Paper.

ZIMMERER, T.W. \& SCARBOROUGH, N.M. 2005. Essentials of entrepreneurship and small business management. $\left(4^{\text {th }}\right.$ ed.) US: Pearson. 